\title{
POLITYKA WIZERUNKOWA HASZYMIDZKIEGO KRÓLESTWA JORDANII ZE SZCZEGÓLNYM UWZGLĘDNIENIEM ROLI PIERWSZEJ DAMY
}

ABSTRACT Impression Management Policy of the Jordanian Royal Family with special attention to the position of the first lady

Impression Management Policy of the Hashemite Kingdom of Jordan is the image creation of this country within and outside its borders. The main actors in this process are the King and the Queen. This image is diversely interpreted and every so often is on the verge of suppressing the reality. In Jordan, the mission of the King in creating a plausible image of his country seems to be largely complicated. The monarch has to reconcile different groups of people, such as conservatives or refugees with economical dependency to the USA, Israel or Saudi Arabia and Iraq. The Hashemite Monarchy is a particular case among the Middle Eastern countries, because the role of the Queen in public life is crucial. With the exception of the King, photographs of the royal family, or even the Queen alone, are often encountered. The present Jordanian Queen, Rania Al-Abdullah, is one of the most recognized Middle Eastern women, mostly because of her skilful promotion in worldwide media. The Queen is chiefly promoting education, women and children's rights and charity organizations. The image of the country created by the Queen is parallel to the King's activity and also affects his image positively.

KEYWORDS Jordan, Hashemite Royal Family, Impression Management Policy, Abdullah II, Rania Al-Abdullab 


\section{WSTĘP}

Polityka wizerunkowa Jordanii to przede wszystkim kreowanie wizerunku państwa poprzez działalność króla i królowej. Polityka ta jest istotnym czynnikiem służącym zapewnieniu panującej dynastii silnej pozycji oraz zdobyciu przychylności zarówno obywateli, jak i zagranicznych obserwatorów. Samo kreowanie wizerunku jest ogótem dziatań, jakie czyni podmiot [...] w celu jego wypromowania i utrzymania sie $w \dot{z} y-$ ciu politycznym. Na taka forme promowania wtadzy sktadaja się wypowiedzi, zachowania, określone postępowanie, kontakty z uczestnikami sceny politycznej, wyglad ${ }^{1}$. Kreowanie wizerunku to coraz częściej wykorzystywane przez polityków narzędzie public relations $^{2}$. Według Yei-Yi Chena i Wen Chang Fanga polityka wizerunkowa stanowi konkretny rodzaj zachowania polityków, stosowany w celu otrzymania pożądanych wyników. Ma ścisły związek z działalnością danego podmiotu oraz tym, jak jest postrzegany ${ }^{3}$.

Mimo że powstało wiele opracowań dotyczących Haszymidzkiego Królestwa Jordanii, m.in. biografie króla Husajna I Hussein ofJordan Jamesa Lunta z 1989 r. i Lion ofJordan Aviego Shlaima z 2007 r. ${ }^{4}$, badania jordańskich elit politycznych w kontekście marketingu politycznego nie są szeroko rozpowszechnione. Informacje na ten temat pochodzą zazwyczaj z opracowań dotyczących całego regionu Bliskiego Wschodu.

Jordania, chociażby ze względu na uzależnienie gospodarki od Stanów Zjednoczonych, Izraela (dostawy wody) czy Arabii Saudyjskiej oraz Iraku (zaopatrywanie $\mathrm{w}$ ropę naftową), jest skomplikowanym i interesującym przypadkiem kreowania wizerunku. Rządzący monarcha stara się godzić tradycje arabskie i muzułmańskie z zagranicznymi interesami państwa. Dodatkową komplikacją jest kwestia uchodźców, głównie palestyńskich, ale też syryjskich i irackich, którzy stanowią znaczny odsetek ludności Jordanii (zob. 2.3.). Rządzący muszą więc tworzyć wizerunek, który zostanie zaakceptowany przez tak odmienne społeczności.

Omawiając zagadnienie wizerunku Haszymidzkiego Królestwa Jordanii, nie sposób pominąć wyraźnie zeuropeizowanego wizerunku monarchy i jego rodziny. Zachodni

1 K. Giereło, Wizerunek (image) polityka - teoria i praktyka, [w:] Public relations w teorii i praktyce, red. B. Ociepka, Wrocław 2002, s. 20.

2 Powstało wiele publikacji na temat sprawnego kreowania wizerunku z punktu widzenia psychologii (zob. np. R. B. Felson, Aggression as Impression Management, „Social Psychology” 1978, vol. 41, nr 3, s. 205-213, [online] http://dx.doi.org/10.2307/3033557), biznesu (zob. np. P. Rosenfeld, Impression Management, Fairness, and the Employment Interview, „Journal of Business Ethics” 1997, vol. 16, nr 8, s. 801-808, [online] http://dx.doi.org/10.1023/A:1017972627516) czy religii (zob. np G. K. Leak, S. Fish, Religious Orientation, Impression Management, and Self-Deception: Toward a Clarification of the Link between Religiosity and Social Desirability, ,Journal for the Scientific Study of Religion” 1989, vol. 28, nr 3, s. 355-359, [online] http://dx.doi.org/10.2307/1386746).

3 Y. Y. Chen, W. C. Fang, The Moderating Effect of Impression Management on the Organizational Politics - Performance Relationship, „Journal of Business Ethics” 2008, vol. 79, nr 3, s. 264, [online] http://dx.doi.org/10.1007/s10551-007-9379-3.

4 A. Shlaim, Lion of Jordan. The Life of King Hussein in War and Peace, New York 2008. 
styl życia przejawia się już w ubiorze króla (oraz jego najbliższych) widocznym na zdjęciach zamieszczanych na jego stronie internetowej i profilach na portalach społecznościowych oraz rozwieszonych w większości miejsc użytku publicznego. Jest to fenomen charakterystyczny dla Bliskiego Wschodu, jednak w Haszymidzkim Królestwie szczególnie rozpowszechniony. W innych monarchiach arabskich rzadziej można natrafić na zdjęcie króla z żoną i dziećmi, choć podobizny jego samego są bardzo często spotykanes. Według Iwony Król wykorzystanie do autopromocji monarchy mediów społecznościowych, w szczególności zamieszczanie w nich fotografii, prowadzi do zdobycia popularności, która wpływa na przychylny odbiór opinii publicznej. Władcy, prezentując sceny ze swojego życia codziennego, pokazują, że żyją w tym samym świecie, co ich poddani. W ten sposób osłabiona zostaje bariera pomiędzy nimi ${ }^{6}$.

Celem niniejszego artykułu jest analiza działalności króla i królowej w zakresie kreowania wizerunku swojego oraz Jordanii, w kraju i za granicą. W artykule przedstawiono cechy charakterystyczne dla jordańskiej polityki wizerunkowej, odpowiedziano również na pytania o to, z jakim odbiorem społecznym owa polityka się spotyka oraz czym różni się kreowanie wizerunku wewnątrz i na zewnątrz państwa. Ważną kwestią podjętą w tekście jest rola, jaką w jordańskiej polityce wizerunkowej odgrywa pierwsza dama. Rania, obecna królowa Jordanii, to postać bardzo medialna. Nie ulega wątpliwości, że przez aktywną działalność, szczególnie na rzecz rozwoju oświaty czy praw kobiet, stała się swego rodzaju ikoną nowoczesnej kobiety arabskiej, zarówno w Jordanii, jak i poza jej granicami.

Metodą badawczą zastosowaną $\mathrm{w}$ artykule była analiza jakościowa informacji podawanych w języku angielskim i arabskim przez rodzinę królewską, znajdujących się na ich licznych profilach na portalach społecznościowych. Narzędziami pomocniczymi były obserwacja uczestnicząca oraz rozmowy z Jordańczykami na temat postrzegania przez nich własnego państwa i działalności rodziny królewskiej. W pracy wykorzystano także publikacje poświęcone Jordanii. Jednakże najistotniejszą rolę odegrały źródła elektroniczne, takie jak: osobiste strony internetowe króla i królowej, ich profile na portalach społecznościowych, oraz autobiografia króla Abd Allaha II, wydana w 2011 r. w języku angielskim, następnie przetłumaczona na inne języki, w tym na język arabski.

Praca składa się ze wstępu, trzech części i podsumowania. Część pierwsza przybliża sylwetkę Abd Allaha II oraz charakteryzuje główne założenia jego polityki. Część druga opisuje aspekty kreowania wizerunku Jordanii w kraju oraz poza jego granicami. Część trzecia skupia się natomiast na charakterystyce roli pierwszej damy Jordanii w kreowaniu wizerunku państwa.

Osobiste obserwacje z wizyt w Jordanii (2009 i 2012) i w Maroku (2010).

6 I. Król, Sposoby kreowania wizerunku monarchy w Jordanii, Maroku i Arabii Saudyjskiej, [w:] Kultura popularna na Bliskim Wschodzie, red. nauk. K. Górak-Sosnowska, K. Pachniak, Warszawa 2013, s. 153. 


\section{KRÓL ABD ALLAH II}

Abd Allah II, syn panującego prawie pół wieku króla Husajna I, w chwili objęcia tronu miał 36 lat. Choć nowy władca nie był przygotowany na to, że zostanie królem, był dobrze zaznajomiony z jordańską polityką; często towarzyszył królowi Husajnowi w podróżach zagranicznych. Podobnie jak jego ojciec i dziadek, zdobył wykształcenie w Wielkiej Brytanii i w Stanach Zjednoczonych. Jako że jest wojskowym (ukończył Royal Military Academy Sandhurst w Wielkiej Brytanii ${ }^{7}$ ), miał też poparcie wpływowych w państwie armii i służb specjalnych ${ }^{8}$. Król Abd Allah II w 1993 r. poślubił Ranię Al-Jasin. Tytuł królowej nadano jej w marcu 1999 r. ${ }^{9}$ Abd Allah i Rania mają czwórkę dzieci: synów - Husajna (ur. 1994), który jest następcą tronu, i Haszima (ur. 2005), oraz córki Iman (ur. 1996) i Salmę (ur. 2000) ${ }^{10}$.

Sytuacja polityczna, jaką zastał Abd Allah II, obejmując tron, pomimo tymczasowej stabilności wewnętrznej, nie była jednak łatwa. Trwał konflikt izraelsko-palestyński, aktualna pozostawała też potrzeba zachowania dobrych relacji z państwami, które wspierały Jordanię finansowo czy gospodarczo: Irakiem, głównym dostawcą ropy naftowej, Stanami Zjednoczonymi - ze względu na dotacje - oraz Izraelem, dostarczającym wodę pitną. W 1999 r., niedługo po intronizacji, Abd Allah II wysłał do ówczesnego premiera Izraela Binjamina Netanjahu list, w którym zapewnił, że chce kontynuować politykę ojca w celu osiągnięcia pokoju na Bliskim Wschodzie i uregulowania konfliktu izraelsko-palestyńskiego ${ }^{11}$. W grudniu 1999 r. Jordania została przyjęta do Światowej Organizacji Handlu ${ }^{12}$, a w październiku 2000 r. podpisała z USA układ o wolnym handlu. Posunięcie to wpisywało się w politykę modernizacji i reform gospodarczych, jakie chciał przeprowadzić Abd Allah. Porozumienie, po zaakceptowaniu przez Kongres, zaowocowało zwiększeniem pomocy finansowej dla Jordanii, co uplasowało ją na czwartym miejscu (po Izraelu, Egipcie i Kolumbii ${ }^{13}$ ) pod względem wysokości tegoż wsparcia. Ratyfikacja traktatu o wolnym handlu wywołała sprzeciw ugrupowań opozycyjnych; doszło do masowych protestów, które zbiegły się w czasie z wybuchem drugiej intifady w Palestynie. Protestujący krytykowali prozachodnią, a szczególnie proizraelską politykę prowadzoną przez monarchę ${ }^{14}$. Demonstracje oraz napięta sytuacja międzynarodowa ${ }^{15}$ spowodowały zaostrzenie reżimu politycznego.

Abdullah II, Our Last Best Chance. A Story of War and Peace, New York 2012, s. 48.

B. Wróblewski, Jordania, Warszawa 2011, s. 249.

Abdullah II, Our Last Best Chance..., s. 77, 137.

10 Profile, oficjalna strona internetowa króla Abd Allaha II, [online] http://kingabdullah.jo/index.php/ en_US/pages/view/id/148.html, 20 XII 2014.

11 J. Zdanowski, Historia Bliskiego Wschodu wXX wieku, Wrocław 2010, s. 470.

12 B. Wróblewski, Jordania, s. 235.

13 D. Madeyska, Historia wspótczesna świata arabskiego, Warszawa 2008, s. 79.

14 B. Wróblewski, Jordania, s. 251-252.

15 D. Madeyska, Historia wspótczesna..., s. 80. 
Król przełożył wybory zaplanowane na 2001 r. aż na 2003 r. W 2001 r. Abd Allah II potępił zamachy terrorystyczne na World Trade Center. Jordania przyłączyła się do koalicji antyterrorystycznej z zastrzeżeniem, że przyczyni się ona także do rozwiązania problemu palestyńskiego oraz nie doprowadzi do ataku na żadne z państw arabskich. Inwazja Stanów Zjednoczonych na Irak w 2003 r. sprawiła, że Haszymidzkie Królestwo wycofało się z sojuszu i nie pozwoliło na przeprowadzenie ataków na Irak ze swojego terytorium ${ }^{16}$.

W 2011 r. Jordania nie była wolna od protestów związanych z tzw. Arabską Wiosną Ludów. Demonstracje, które rozpoczęły się w styczniu, ucichły po czterech miesiącach. Protestujący krytykowali autorytarny i prozachodni sposób sprawowania władzy oraz sytuację gospodarczą państwa. Niektóre z haseł wznoszonych przez demonstrantów wzywały do buntu, który doprowadzi do zmniejszenia głodu, bezrobocia i ubóstwa $\mathrm{w}$ Jordanii ${ }^{17}$. Ważnym wydarzeniem było wystosowanie 10 lutego przez konfederację plemion beduińskich listu otwartego do króla. Atakowano w nim rodzinę królewską, w tym królową Ranię, oskarżając ją o nepotyzm i korupcję. Manifestacje w Jordanii nie były jednak tak gwałtowne jak w Egipcie, Tunezji czy Libii. Reakcją króla było zdymisjonowanie premiera Samira Zaida al-Rifaiego oraz zapowiedź zmian w konstytucji i przyspieszenia reform demokratycznych ${ }^{18}$. Pomimo głosów niezadowolenia, wśród Jordańczyków panuje przekonanie, iż króla nie należy zmieniać czy za wszelką cenę obalać ${ }^{19}$. Powinno się natomiast nakłaniać go do wprowadzenia zmian, które zapewniłyby jego poddanym lepszy byt, oraz zwiększenia swobód obywatelskich, takich jak zmniejszenie cenzury.

\section{ASPEKTY KREOWANIA WIZERUNKU WEWNĘTRZNEGO I ZEWNĘTRZNEGO JORDANII}

\subsection{Wizerunek wewnętrzny i zewnętrzny}

Skuteczne kreowanie pozytywnego wizerunku przez rodzinę królewską to trudne zadanie, niełatwo bowiem usatysfakcjonować konserwatywne grupy muzułmańskie czy nastawionych antyizraelsko Palestyńczyków zamieszkujących Jordanię, będąc jednocześnie gospodarczo uzależnionym od Stanów Zjednoczonych. Starając się uspokoić nastroje społeczne, rodzina królewska promuje ideały patriotyczne, często odwołując się do islamu, np. przez podkreślanie swojego pokrewieństwa z prorokiem Mahometem czy tradycyjnego prawa do sprawowania opieki nad świętymi miejscami ${ }^{20}$. Widać

\footnotetext{
Tamże, s. 79.

17 Y. Moon, Democracy on the Horizon: How the Arab Spring is Unfolding in Jordan, "Harvard International Review" 2012, vol. 33, issue 4, s. 28.

18 J. Zdanowski, Bliski Wschód 2011. Bunt czy rewolucja?, Kraków 2011, s. 223.

19 B. Wróblewski, Jordania, s. 251-252.

20 Abdullah II, Our Last Best Chance..., s. 20.
} 
to już w pierwszych zdaniach biografii króla zamieszczonej na jego oficjalnej stronie internetowej ${ }^{21}$. Na zewnątrz zaś Królestwo Jordanii jawi się jako otwarta i tolerancyjna monarchia bliskowschodnia, której władze starają się iść z duchem czasu, jednocześnie budując obraz nowoczesnej elity arabskiej. Objawia się to noszeniem zachodniego ubioru, częstą publikacją zdjęć z życia codziennego, np. przedstawiających jazdę na motocyklu ${ }^{22}$, czy wyraźnym udziałem pierwszej damy w życiu publicznym i jej działalnością, np. na rzecz praw kobiet.

Istotnym elementem kreowania wizerunku króla Abd Allaha II, w kraju i za granicą, jest podkreślanie jego pozycji jako zwierzchnika sił zbrojnych oraz wojskowego. Publikowanie zdjęć króla w mundurze z najwyższymi odznaczeniami wojskowymi ma przekonać obywateli o tym, że jako głowa państwa jest on w stanie obronić ojczyznę w razie niebezpieczeństwa, a zewnętrznych obserwatorów utwierdzić w przekonaniu, że król jest liczącym się na scenie międzynarodowej graczem. Przykładem takiej polityki jest m.in. ostatnia, szeroko komentowana, zdecydowana reakcja Abd Allaha II na spalenie żywcem jordańskiego pilota przez bojowników Państwa Islamskiego $(\text { ISIS })^{23}$ : Jordania odpowiedziała serią intensywnych nalotów lotniczych oraz egzekucją bojowników związanych z ISIS ${ }^{24}$. W zagranicznych mediach pojawiły się nawet - szybko zdementowane - pogłoski, jakoby król miał osobiście bombardować tereny Państwa Islamskiego ${ }^{25}$. Z otwartą krytyką działań ISIS wystąpiła również królowa Rania, wielokrotnie podkreślając, że działalność bojowników nie ma nic wspólnego $\mathrm{z}$ islamem ${ }^{26}$.

Choć wizerunek Jordanii jako nowoczesnego państwa nie przystaje do obecnej wciąż w mediach cenzury i szeregu innych ograniczeń obywatelskich, to nacisk kładziony na zewnętrzne działania promocyjne zwiększa się.

\subsection{Autorytaryzm czy demokracja?}

Jordania jest monarchią konstytucyjną. Ustawa zasadnicza została uchwalona w 1952 r. i wiązała się m.in. z legalizacją systemu partyjnego. Król pozostaje zwierzchnikiem ar-

21 Profile, oficjalna strona internetowa króla Abd Allaha II, [online] http://kingabdullah.jo/index.php/ en_US/pages/view/id/148.html, 20 XII 2014.

22 I. Król, Sposoby kreowania wizerunku monarchy..., s. 156.

23 Jordan Carries Out New Air Strikes After Pilot's Murder, www.theguardian.com, 5 II 2015, [online] http://www.theguardian.com/world/2015/feb/05/jordan-air-strikes-isis-pilot-murder, 6 III 2015.

24 R. Nordland, D. D. Kirkpatrick, Jordan's King Abdullah II Returns Home to Cheers After Swift Executions, www.nytimes.com, 4 II 2015, [online] http://www.nytimes.com/2015/02/05/world/middleeast/ jordans-king-abdullah-ii-returns-home-to-cheers-after-swift-executions.html?_r=0, 6 III 2015.

25 G. Mezzofiore, No, Jordan's King Abdullah II Is Not Personally Flying Planes Against Isis, „International Business Times", 5 II 2015, [online] http://www.ibtimes.co.uk/no-jordans-king-abdullah-ii-not-personally-flying-planes-against-isis-1486742, 6 III 2015.

26 K. Miles, Queen Rania: Let's Drop The First «I»In ISIS. There’s Nothing Islamic About Them, „The WorldPost", 6 III 2015, [online] http://www.huffingtonpost.com/2015/03/06/queen-rania-isis-islamic_n_6781160.html, 6 III 2015. 
mii, policji oraz całego korpusu dyplomatycznego ${ }^{27}$. System wielopartyjny został jednak zawieszony przez wprowadzenie stanu wojennego w 1967 r.; trwał on aż do $1992 \mathrm{r}$. i zapewnił monarsze niemal absolutną władzę. W Jordanii w latach $70 . \mathrm{XX}$ w., w czasach dyktatury wojskowej, bardzo ważną funkcję pełnili pracownicy służb specjalnych, kontrolujący administrację państwową. Ówczesny wzrost autorytaryzmu zapewnif Haszymidzkiemu Królestwu stabilizację wewnętrzną, pożądaną w obliczu nieustającego konfliktu z Izraelem ${ }^{28}$. Koniec lat 80 . i początek 90. to okres demokratycznych przemian: król Husajn zniósł stan wojenny, przywrócił pluralizm partyjny oraz wolne wybory. Dziś zarejestrowane są 23 partie polityczne ${ }^{29}$. Dzięki temu parlament zaczął pełnić mniej fasadową funkcję niż dotychczas. Główne prerogatywy władzy należały jednak wciąż do monarchy. W konstytucji Jordanii, w rozdziale Król i jego prerogatywy, znajduje się zapis mówiący, że król pełni głównie władzę wykonawczą, ale również ustawodawczą, m.in. przez bezpośredni wybór członków izby wyższej parlamentu ${ }^{30}$.

Choć promowanie liberalnych reform i powoływanie się na demokratyczne ideały jest jednym z elementów królewskiej polityki wewnętrznej i zagranicznej, zakres władzy monarchy wciąż pozostaje właściwie nieograniczony. Król kontroluje parlament i cały system polityczny ${ }^{31}$. Prasa nie może publikować negatywnych komentarzy na jego temat, a krytyka jest natychmiastowo zwalczana aresztowaniami dziennikarzy czy działaczy partyjnych. W 2002 r. zamknięto biuro telewizji Al-Dżazira w Ammanie. Szacuje się, że od 1999 do 2003 r. rząd wydał ponad 100 tymczasowych dekretów ograniczających swobody obywatelskie, uzasadniając je walką z terroryzmem ${ }^{32}$.

Mimo że jordański ustrój nie jest demokratyczny, w porównaniu z innymi państwami regionu Haszymidzkie Królestwo gwarantuje wiele swobód obywatelskich. Cztery dotychczasowe edycje Arab Democracy Index (2008, 2009, 2010, 2012), przygotowanego przez The Arab Reform Initiative (ARI), wskazują, że Jordania znajduje się pod tym

\footnotetext{
B. Wróblewski, Jordania, s. 125-126.

Tamże, s. 181-182.
}

29 Jordan, The World Factbook, Central Intelligence Agency, 20 VI 2014, [online] https://www.cia. gov/library/publications/the-world-factbook/geos/jo.html, 20 XII 2014.

Zgromadzenie Narodowe, sprawujący władzę ustawodawczą dwuizbowy parlament jordański, składa się z Izby Deputowanych (izba niższa) i Senatu (izba wyższa). Władza wykonawcza spoczywa w rękach króla oraz premiera z Radą Ministrów (wybieraną przez premiera w konsultacji z królem). W skład niższej izby parlamentu wchodzi 150 członków, wybieranych w wyborach powszechnych, z czego 6 miejsc jest zarezerwowanych dla kobiet, 9 dla kandydatów beduińskich, 9 dla chrześcijan oraz 3 dla mniejszości czeczeńskiej i czerkieskiej. Skład izby wyższej to 60 senatorów, wskazywanych bezpośrednio przez króla. Kadencja parlamentu trwa cztery lata, jednak jeżeli wymaga tego sytuacja, król może ją przedłużyć bądź skrócić. Przykładem takiego postępowania jest decyzja o przedłużeniu kadencji Izby Deputowanych o dwa lata w 2001 r., zdeterminowana obawą króla o to, że wybory mogą wygrać bardzo wpływowi wówczas Bracia Muzułmanie, którzy często kontestowali monarszą politykę. Konstytucja Jordanii jest dostępna na oficjalnej stronie króla Husajna: The Constitution of The Hashemite Kingdom of Jordan January 1, 1952, [online] http://www.kinghussein.gov.jo/constitution_jo.html, 20 XII 2014; B. Wróblewski, Jordania, s. 252-254.

31 B. Wróblewski, Jordania, s. 263.

32 D. Madeyska, Historia wspótczesna..., s. 80. 
względem w ścisłej czołówce państw arabskich. W rankingu brano pod uwagę następujące wskaźniki: pozycja i gotowość na przyjęcie krytyki instytucji publicznych w kraju, poszanowanie praw i swobód obywatelskich, równość i sprawiedliwość społeczna oraz rządy prawa. W 2008 i 2012 r. Jordania uplasowała się na drugim miejscu - za Marokiem. W 2009 r. zajęła pierwszą pozycję, natomiast w 2010 r. - czwartą (za Marokiem, Libanem i Kuwejtem $)^{33}$. Jednakże na tle globalnym ustrój Jordanii klasyfikowany jest jednoznacznie jako reżim autorytarny. Ranking Democracy index przygotowywany od 2006 r. przez The Economist Intelligence Unit (EIU) wyróżnia cztery typy ustrojów: pełne demokracje, wadliwe demokracje, reżimy hybrydowe oraz reżimy autorytarne. Pod uwage brane są następujące wskaźniki: kultura polityczna, wolne wybory i swobody obywatelskie. Ustrój Jordanii jest konsekwentnie zaliczany do reżimów autorytarnych, ale znajduje się wśród nich na wysokiej pozycji: w 2006 r. Jordania uplasowała się na 113. miejscu (na 167, zajmując przy tym 1. miejsce w grupie reżimów autorytarnych ${ }^{34}$ ), w 2008 i 2010 r. zajęła 117. miejsce (odpowiednio 1. i 5. miejsce w grupie reżimów autorytarnych $)^{35}$, w 2011 r. - 118. (3. miejsce w grupie) ${ }^{36}$, w 2012 - 121. (5. miejsce w grupie) ${ }^{37}$, w 2013 - 122. (6. miejsce w grupie) $)^{38}$, a w 2014 - 121. (6. miejsce w grupie ${ }^{39}$. Pozycja Jordanii w rankingu demokracji spadła więc na przełomie ostatnich lat, co wskazuje na umacnianie się autorytarnej formy ustrojowej. Czynnikami spowalniającymi proces demokratyzacji i liberalizacji ustroju i systemu politycznego Jordanii są bardzo duża liczba uchodźców i stały wyż demograficzny. Jordania boryka się również z problemami gospodarczymi, takimi jak stale rosnące zadłużenie, i strukturalnymi, m.in. wysokim bezrobociem (sięgającym nawet $25 \%)^{40}$.

33 Arab Reform Initiative, Arab democracy index, [online] http://www.arab-reform.net/sites/default/ files/ADI-IV_Mastersheet.pdf, 6 III 2014.

34 The Economist Intelligence Unit's index of democracy. The World in 2007, London 2007, s. 5, [online] http://www.economist.com/media/pdf/DEMOCRACY_INDEX_2007_v3.pdf, 6 III 2014.

35 The Economist Intelligence Unit's Index of Democracy 2008, London 2009, s. 7, [online] http://graphics.eiu.com/PDF/Democracy\%20Index\%202008.pdf, 6 III 2014; Democracy index 2010. Democracy in retreat. A report from the Economist Intelligence Unit, London 2010, s. 6, [online] https://graphics. eiu.com/PDF/Democracy_Index_2010_web.pdf, 6 III 2014.

36 Democracy index 2011. Democracy under stress. A report from the Economist Intelligence Unit, London 2011, s. 7, [online] http://www.eiu.com/public/topical_report.aspx ?campaignid=DemocracyIndex2011, 6 III 2014.

37 Democracy index 2012. Democracy at a standstill. A report from The Economist Intelligence Unit, London 2013, s. 7, [online] http://www.eiu.com/public/topical_report.aspx ?campaignid=DemocracyIndex 12, 6 III 2014.

38 Democracy index 2013. Democracy in limbo. A report from The Economist Intelligence Unit, London 2014, s. 6, [online] http://www.eiu.com/public/topical_report.aspx?campaignid=Democracy0814, 6 III 2014.

39 Democracy Index 2014. Democracy and its discontents. A report from The Economist Intelligence Unit, London 2015, s. 7, [online] http://www.eiu.com/public/topical_report.aspx?campaignid=Democracy0115, 6 III 2014.

B. Wróblewski, Jordania, s. 262-263. 


\subsection{Kreowanie tożsamości jordańskiej}

Zagadnienie tożsamości narodowej nie jest łatwe do zdefiniowania. W przypadku Jordanii jej określenie i wykreowanie jest skomplikowanym procesem, determinowanym wieloma czynnikami. 98\% mieszkańców Jordanii to Arabowie, zaś ludnością autochtoniczną są beduini. Oficjalnie podaje się, że $92 \%$ populacji to muzułmanie, a $6 \%$ - chrześcijanie ${ }^{41}$. To właśnie tożsamość arabsko-muzułmańska w dużej mierze określa Jordańczyków. Poszczególni królowie Jordanii byli również muzułmanami, a jako Haszymidzi zawsze podkreślali przynależność do rodu proroka Mohameta ${ }^{42}$, co pomagało im zdobyć szacunek i lojalność społeczeństwa. Jednak sama identyfikacja religijna mieszkańców danego państwa, bez poczucia przynależności narodowej, to za mało, by zapewnić mu trwałość.

Istotną przeszkodą w kreowaniu jordańskiej tożsamości jest to, że znaczną część jej społeczeństwa stanowią uchodźcy z państw, w których poczucie przynależności narodowej jest silniejsze niż u Jordańczyków. W związku z wojnami i niestabilną sytuacją polityczną w regionie Jordania już od lat 50 . XX w. przyjmowała rzesze uchodźców; na początku z Palestyny, później z Iraku, a od 2011 r. - z Syrii. Jordanię zamieszkuje $6,5 \mathrm{mln}$ osób $^{43}$, z czego prawie $2 \mathrm{mln}$ to Palestyńczycy, 377 tys. stanowią Syryjczycy, a 29 tys. - uchodźcy z Iraku ${ }^{44}$. Jak twierdzi sam król Abd Allah II, już w 1999 r. szacowało się, iz $43 \%$ obywateli Jordanii ma palestyńskie powiązania rodzinne, a liczba ta zapewne wzrosła, chociażby ze względu na mieszane małżeństwa ${ }^{45}$. Budowaniu tożsamości jordańskiej nie sprzyja także fakt, iż jest to państwo o stosunkowo krótkiej historii, pozbawione dlugoletnich tradycji narodowych, w przeciwieństwie np. do Egiptu, odwołującego się do starożytnych korzeni, czy Iraku, na terenie którego rozwijał się kalifat abbasydzki.

W 2002 r. została podjęta inicjatywa pod hasłem Jordan First. Kampania miała zaszczepić w mentalności mieszkańców królestwa patriotyzm jordański, w szczególności promować przekonanie, że interesy Jordanii powinny być na pierwszym miejscu, przed interesami ogólnoarabskimi ${ }^{46}$. Jak twierdzi Bartosz Wróblewski, inicjatywa miała raczej charakter propagandowy i nie przyniosła większych zmian w społeczeństwie ${ }^{47}$.

Próbę krzewienia wśród Jordańczyków świadomości narodowej stanowi również promowanie dziedzictwa historycznego oraz tradycyjnych wyrobów rękodzielniczych.

41 Jordan, The World Factbook, Central Intelligence Agency, 20 VI 2014, [online] https://www.cia. gov/library/publications/the-world-factbook/geos/jo.html, 20 XII 2014.

Jordan, The World Factbook...

Refugees and Internally Displaced Persons, The World Factbook, Central Intelligence Agency, [online] https://www.cia.gov/library/publications/the-world-factbook/fields/2194.html, 20 XII 2014.

Abdullah II, Our Last Best Chance..., s. 153.

Jordan First, oficjalna strona internetowa króla Abd Allaha II, [online] http://kingabdullah.jo/index. php/en_US/initiatives/view/id/3.html, 20 XII 2014.

7 B. Wróblewski, Jordania, s. 254. 
Przykładem może być projekt Narodowy Rozwój Rękodzieła, podjęty przez fundację Królowej Noor (czwarta żona króla Husajna) w połowie lat 80. Jedną z inicjatyw w jego ramach było wspieranie działalności tkackiej w miejscowości Bani Hamida. Beduinki wykonywały tkaniny w sposób tradycyjny, wykorzystując charakterystyczne dla rejonu hafty i wzory. Królowa Noor sama zaczęła nosić suknie z Bani Hamidy, rozpoczynając tym samym modę na tradycyjne jordańskie stroje, które stały się znane w całym regionie $^{48}$. Innym pomysłem królowej, również związanym z promowaniem dziedzictwa Jordanii, był festiwal w Dżarasz, który odbywa się corocznie od 1980 r. Trwające trzy tygodnie wydarzenie, podczas którego odbywają się przedstawienia teatralne oraz widowiska muzyczne i taneczne, ma promować jordańską kulturę i folklor. To jeden z najbardziej prestiżowych festiwali odbywających się w Jordanii ${ }^{49}$. Sposobem akcentowania jordańskości jest również powszechna obecność flagi państwowej w przestrzeni publicznej.

\subsection{Jordania jako państwo proamerykańskie}

Od ok. 1957 r. Stany Zjednoczone zaczęły przejmować wpływy Wielkiej Brytanii w Haszymidzkim Królestwie. Waszyngton zaczął wówczas udzielać Jordanii regularnej pomocy finansowej oraz dostarczać jej broń i inny sprzęt wojskowy ${ }^{50}$. Obecnie państwo to otrzymuje od USA rocznie prawie 1 mld dolarów bezzwrotnej pomocy finansowej (czwarte miejsce na liście beneficjentów) ${ }^{51}$. Nie ulega wątpliwości, że kwestia utrzymania jak najlepszych stosunków z Waszyngtonem należy do priorytetów polityki zagranicznej Ammanu. Dobre relacje z Jordanią są zaś korzystne dla USA ze względu na jej położenie geopolityczne (granica z Izraelem, Irakiem, Arabią Saudyjską) oraz relacje z Izraelem ${ }^{52}$.

Król Husajn przez cały okres swych rządów starał się o utrzymanie dobrych stosunków z Waszyngtonem, jednak nie była to polityka jednoznaczna; określa się ją mianem polityki elastycznego balansowania ${ }^{53}$. Król nie wahał się podejmować decyzji, które uważał za słuszne, a które mogły - co prawda krótkotrwale - nadszarpnąć dobre relacje między państwami. Przykładem może być długoletnia lojalność Jordanii wobec Saddama Husajna i jego polityki. Podczas inwazji na Kuwejt król Jordanii nie przyłączył się do antyirackiej koalicji. Jego postępowanie było motywowane interesami państwa - popieranie Saddama łączyło się z możliwością odzyskania Zachodniego Brzegu ${ }^{54}$.

48 Noor, Autobiografia. Opowieść o nieoczekiwanym życiu, przeł. B. Cendrowska, Warszawa 2003, s. 219-223.

49 Tamże, s. 154.

50 K. Czornik, Królestwo Jordanii w polityce Stanów Zjednoczonych wobec Bliskiego Wschodu w okresie pozimnowojennym, „Studia Politicae Universitatis Silesiensis” 2014, t. 12, s. 135.

51 B. Wróblewski, Jordania, s. 263.

52 K. Czornik, Królestwo Jordanii w polityce..., s. 133.

53 Tamże, s. 139.

54 Jordania podczas głosowania Ligi Państw Arabskich nad rezolucją potępiającą aneksję Kuwejtu wstrzymała się od głosu. Husajn I poparł ultimatum Saddama Husajna, który twierdził, iż wycofa wojska z Kuwejtu, jeśli Izrael ewakuuje się z Zachodniego Brzegu. Zob. J. Zdanowski, Historia Bliskiego Wschodu..., s. 462-463. 
Król potępił bombardowania Bagdadu, a samą wojnę określił mianem barbarzyńskiej $i$ totalnej5. Reakcją Stanów Zjednoczonych było wstrzymanie pomocy gospodarczej dla Jordanii ${ }^{56}$. Relacje między państwami poprawiły się w połowie lat 90., głównie dzięki podpisaniu przez Jordanię traktatu pokojowego z Izraelem w $1994 \mathrm{r}$. Wówczas prezydent Bill Clinton obiecał umorzenie jordańskich długów o wysokości 702,3 mln dolarów. Stało się ono faktem w $1997 \mathrm{r}^{.57}$

Abd Allah II wydaje się bardziej zdeklarowanym sprzymierzeńcem USA, jednak stara się także być lojalny wobec państw arabskich. Przeciwnicy króla (fundamentaliści muzułmańscy oraz część Palestyńczyków) zarzucają mu, że jest marionetką w rękach Stanów Zjednoczonych i Zachodu. Postrzegają go jako moralnego cudzoziemca, a potwierdzeniem tego ma być fakt, że król kształcił się i praktycznie wychował w Wielkiej Brytanii i USA, co więcej - jego matka, Antoinette Avril Gardiner, jest Brytyjką ${ }^{58}$. Objawami niezadowolenia wobec polityki króla są protesty, takie jak te z 2000 r., które odbyły się po podpisaniu przezeń układu o wolnym handlu.

Proamerykańska polityka pomaga Jordanii w modernizacji gospodarczej. Kultura Zachodu, zgodnie ze światową tendencją, przenika również do życia codziennego w królestwie. W Jordanii bardzo modny stał się więc język angielski. Zdarza się, że mieszkańcy - szczególnie młodzi ludzie - władają nim lepiej niż językiem arabskim bądź też mieszają obydwa języki, tworząc swoistą "nowomowę". Jordańczykom nie jest też obca amerykańska popkultura. Świadczy o tym chociażby muzyka, jaką można usłyszeć na ammańskiej ulicy czy nawet w żeńskim akademiku Uniwersytetu Jordańskiego, gdzie znacząca większość dziewcząt nosi hidżab. Również system jordańskiej edukacji ma zachodni profil - jest wzorowany na systemie anglosaskim ${ }^{59}$. Różnice w stopniu zwesternizowania w państwie latwo dostrzec, porównując bogate - zachodnie i uboższe - wschodnie - dzielnice Ammanu oraz jordańską prowincję, która pozostaje bardzo tradycyjna. Sama rodzina królewska wydaje się popierać zachodni styl życia, co przejawia się chociażby w ubiorze. Widać to również na fotografiach króla z żoną i dziećmi, obecnych np. w każdym jordańskim McDonaldzie ${ }^{60}$.

Mimo że Jordania jest postrzegana jako sojusznik Zachodu, zachowuje poprawne stosunki z Iranem, Rosją czy Chinami ${ }^{61}$. Jako kraj o ograniczonym potencjale gospodarczym, demograficznym i terytorialnym, sąsiadujący z o wiele silniejszymi państwami arabskimi oraz Izraelem, potrzebuje równie silnych sojuszników. Zatem przyjazne relacje z USA oraz prozachodnia postawa króla są uzasadnione ${ }^{62}$.

\footnotetext{
55 Tamże, s. 463.

56 Tamże.

57 K. Czornik, Królestwo Jordanii w polityce..., s. 145.

58 B. Wróblewski, Jordania, s. 250, 267.

59 Tamże, s. 272.

60 Osobiste obserwacje z wizyt w Jordanii (2009 i 2012) i w Maroku (2010).

61 A. Malantowicz, Buforowość jako wyznacznik polityki zagranicznej Jordanii, „Stosunki Międzynarodowe" 2014, vol. 49, nr 1, s. 149.

62 K. Czornik, Królestwo Jordanii w polityce..., s. 137-138.
} 


\section{ROLA JORDAŃSKICH PIERWSZYCH DAM W KREOWANIU WIZERUNKU PAŃSTWA}

Katarzyna Giereło podkreśla, że dopiero Hillary Clinton, pierwsza dama Stanów Zjednoczonych w latach 1993-2001, zapoczątkowała nowy styl związany z tą funkcją. Niegdyś informacje dotyczące żony prezydenta czy władcy ograniczały się do jej działalności charytatywnej i kulturalnej. Clinton eksponowała natomiast również swoje dokonania na polu walki o prawa kobiet i mniejszości etnicznych oraz reformy opieki zdrowotnej, stając się medialną gwiazdą. Pierwsza dama przestała być wówczas postrzegana jako tto dla swojego męża ${ }^{63}$. Warto rozważyć, czy taki model możliwy jest w Jordanii, skoro w państwach arabskich często podkreśla się tradycyjną rolę kobiety.

W dzisiejszym świecie arabskim pierwsze damy często angażują się w działalność publiczną, prowadzą fundacje o charakterze charytatywnym, aktywnie działają na rzecz praw kobiet i dzieci (jest to tzw. nowe pokolenie arabskich pierwszych dam). Promują one edukację i przedsiębiorczość i są ikonami swoich państw, pomagającymi mężom w realizowaniu polityki społecznej. Współczesne arabskie żony władców można podzielić na te, których wizerunek jest bardziej zachodni (królowa Rania, księżna Maroka Lalla Salma ${ }^{66}$ ), i te o tradycyjnym stylu (trzecia żona byłego emira Kataru - Moza bint Nasser) ${ }^{65}$. Warto również zauważyć, że styl pierwszej damy jest dopasowany do stylu jej męża.

\subsection{Rola czterech żon króla Husajna I}

Pierwsza żona króla Husajna I, Dina Abdul Hamid, nie odegrała znaczącej roli w jordańskim życiu publicznym, ponieważ małżeństwo trwało bardzo krótko - zaledwie

63 K. Giereło, Wizerunek (image) polityka..., s. 33.

64 Księżna Salma, z wykształcenia inżynier informatyki, zmieniła panujący w Maroku konwenans usuniętej w cień żony króla. Jej udział w życiu publicznym polega głównie na wspieraniu inicjatyw związanych ze zdrowiem. Księżna nie zasłania włosów, ubiera się w sposób europejski, ale nie stroni też od tradycyjnych, bogato zdobionych marokańskich sukni. Mimo że jest często obecna w przestrzeni publicznej, jej działalność nie jest tak rozbudowana i nagłośniona jak w Jordanii. A. Zagner, Żony dyktatorów, „Polityka”, 29 V 2012, [online] www.polityka.pl/tygodnikpolityka/swiat/1527171,1,kochane-nienawidzone-nieznane-arabskie-pierwsze-damy.read, 30 I 2015.

65 Moza bint Nasser jest z wykształcenia socjologiem, ukończyła studia na uniwersytecie w Katarze. Jej strona internetowa przekonuje, że pierwsza dama odgrywa kluczową rolę we wspieraniu dalekosiężnych planów emira, który chce uczynić Katar dobrze prosperującym państwem, z odpowiednio wyedukowanym społeczeństwem. Moza bint Nasser zajmuje się przede wszystkim działalnością na rzecz podnoszenia poziomu edukacji i dostępu do niej. Jest przewodniczącą Qatar Foundation, wiceprzewodniczącą Najwyższej Rady ds. Zdrowia, nadzoruje też działania wielu instytucji promujących zdrowie, edukację i rozwój społeczny. Ubiór pierwszej damy jest zawsze tradycyjny, zasłania włosy oraz całe ciało. Szajcha Moza jest najbardziej znaną i wpływową kobietą w Katarze; towarzysząc mężowi, bierze czynny udział w życiu publicznym państwa. Biography, oficjalna strona internetowa Mozah bint Nasser Al Missned, [online] http://www.mozabintnasser.qa/en/Pages/MozabintNasser/Biography.aspx, 20 XII 2014; K. Górak-Sosnowska, Kobiety w sferze publicznej: edukacja, gospodarka i polityka, [w:] Panstwo Katar. Gospodarka - polityka - kultura, red. K. Górak-Sosnowska, R. Czulda, Łódź 2009, s. 140. 
dwa lata. Husajn poznał swoją drugą żonę w 1961 r. podczas kręcenia w Jordanii filmu Lawrence z Arabii. Antoinette Avril Gardiner, dwudziestoletnia Brytyjka, znana później jako księżna Muna, pracowała wówczas przy jego produkcjii ${ }^{66}$. Po dziesięciu latach małżeństwa para zdecydowała się na rozwód, najprawdopodobniej m.in. dlatego, że młodej Brytyjce trudno było się odnaleźć w realiach etykiety jordańskiego dworu. Muna urodziła czwórkę dzieci, w tym najstarszego syna władcy - Abd Allaha. Zdążyła zająć się działalnością charytatywną, głównie na rzecz poprawy kondycji opieki medycznej w Jordanii. Założyła też szkołę dla pielęgniarek w 1962 r. Po objęciu tronu przez Abd Allaha w 1999 r. jej pozycja w społeczeństwie wzrosła. Księżna Muna w dalszym ciągu działa na rzecz rozwoju instytucji zdrowia publicznego ${ }^{67}$.

Trzecia żona króla Husajna I, królowa Alia, była córką palestyńskiego dyplomaty. Po pięciu latach szczęśliwego małżeństwa, w 1977 r., zginęła w katastrofie helikoptera. Pomimo krótkiego panowania Alia zdążyła aktywnie zaangażować się w działalność publiczną; skupiła się na inicjatywach wspierających rozwój dzieci oraz promujących kulturę i sztukę. Ufundowała m.in. The Haya Arts and Cultural Centre for Child Development. Królowa organizowała również przedsięwzięcia mające na celu walkę z ubóstwem oraz poprawę statusu kobiety w społeczeństwie. Jej imieniem nazwano lotnisko w Ammanie ${ }^{68}$.

Ponad rok po śmierci trzeciej żony król ożenił się po raz czwarty. Jego wybranką została Lisa Halaby, pochodząca z wpływowej rodziny Amerykanka o arabskich korzeniach. Po ślubie Lisa przyjęła imię Noor Al-Husajn. Małżeństwo trwało aż do śmierci króla, czyli ponad 20 lat; w tym czasie Noor urodziła Husajnowi czwórkę dzieci. Zdążyła także na stałe zapisać się na kartach historii Monarchii Haszymidzkiej i w sercach Jordańczyków. Ujmowała skromnością i oddaniem mężowi. Jej styl stał się wyznacznikiem tego, jaka powinna być jordańska pierwsza dama. Pierwszym powierzonym jej przez króla zadaniem było kontynuowanie projektu jej poprzedniczki, związanego z promowaniem jordańskiego folkloru. Owocem tego przedsięwzięcia jest wspomniany już coroczny festiwal kultury i sztuki w Dżarasz. Królowa Noor bardzo aktywnie zaangażowała się także w działalność charytatywną oraz promującą pokojowe rozwiązanie konfliktu palestyńsko-izraelskiego. W 1985 r. powstała fundacja jej imienia, która do dziś zajmuje się realizacją projektów na rzecz szeroko pojętego rozwoju Jordanii. Projekty te dotyczą m.in.: wspierania emancypacji kobiet, opieki społecznej, rozwoju przedsiębiorczości, edukacji i narodowego dziedzictwa ${ }^{69}$.

66 Abdullah II, Our Last Best Chance..., s. 4.

67 Honorary Member. Her Royal Highness Princess Muna Al Hussein, Jordan, oficjalna strona internetowa międzynarodowej organizacji The Honor Society of Nursing, Sigma Theta Tau International, [online] http://www.nursingsociety.org/Awards/international/Pages/HRH_PrincessMuna.aspx, 20 XII 2014.

68 Strona internetowa, na której znajdują się wspomnienia księżniczki Hayi, córki królowej Alii: June Ferguson's Royal Genealogy Page, RootsWeb.com, [online] http://wc.rootsweb.ancestry.com/cgi-bin/ igm.cgi ?op=GET\&db=royals\&id=I33912, 20 XII 2014.

69 Biographical Information. Her Majesty Queen Noor of Jordan, strona internetowa poświęcona królowi Husajnowi, [online] http://www.kinghussein.gov.jo/queen_noor.html, 20 XII 2014. 


\subsection{Działalność królowej Ranii, kreowanie wizerunku państwa}

Obecna królowa Jordanii, żona Abd Allaha II, urodziła się w 1970 r. jako Rania al-Jasin. Pochodzi z palestyńskiej rodziny mieszkającej w Kuwejcie; jej krewni wyemigrowali tam z Zachodniego Brzegu. W 1991 r. Rania ukończyła studia z zakresu ekonomii i marketingu na Amerykańskim Uniwersytecie w Kairze. Podczas I wojny w Zatoce jej rodzina była zmuszona opuścić Kuwejt i przeprowadziła się do Jordanii. Po studiach Rania najpierw znalazła pracę w ammańskim Citybanku, a następnie w Apple Computer Inc. Tam też poznała przyjaciela siostry księcia Abd Allaha, Aishy. W sierpniu 1992 r. ów przyjaciel przyprowadził Ranię na obiad do Aishy, gdzie Abd Allah miał okazję ją poznaćc ${ }^{70}$. Para ogłosiła zaręczyny w lutym 1993 r., a pobrała się kilka miesięcy później. Huczna ceremonia zaślubin była upubliczniona i bardzo medialna; mieszkańcy Ammanu mogli oglądać i pozdrawiać młodą parę przejeżdżającą ulicami stolicy. Przyjęcie zgromadziło ponad 2 tys. gości, w tym hiszpańską królową Zofię oraz ówczesnego następcę tronu Maroka Muhammada ${ }^{71}$. Jako członek królewskiej rodziny Rania była zmuszona porzucić posadę w prywatnej korporacji. Król Husajn zaproponował jej etat w Jordan Export Development and Commercial Centers Corporation, firmie, której zadaniem jest promowanie Jordanii jako atrakcyjnego partnera handlowego na rynkach światowych. W 1994 r. Rania urodziła pierwsze dziecko.

Pozycja księżniczki Ranii, która dotychczas była tylko członkiem bardzo licznej rodziny królewskiej, całkowicie zmieniła się wraz z niespodziewanym wyznaczeniem przez króla Husajna jej męża Abd Allaha na następcę tronu. Niedługo po objęciu tronu, 21 marca 1999 r., Abd Allah II nadał żonie tytuł królowej ${ }^{72}$.

Królowa Rania to jedna z najbardziej rozpoznawanych bliskowschodnich kobiet. Tak jak jej poprzedniczka, jest zaangażowana w życie publiczne, jest też jednak - co odróżnia ją nieco od królowej Noor - osobą bardzo medialną, która nie boi się wykorzystywać najnowszych technologii w celu szerzenia swoich poglądów. Słynie z działalności na rzecz rozwoju oświaty w Jordanii i na świecie oraz z pomocy charytatywnej. Głównym przekonaniem promowanym przez Ranię w świecie jest to, że największe problemy Bliskiego Wschodu nie wynikają z tradycji czy z religii, ale z ograniczonego dostępu do edukacji. Królowa podkreśla, że edukacja jest szansą na poprawę życia, w szczególności kobiet. Może uchronić je przed zbyt wczesnym zamążpójściem, zabójstwami honorowymi (zob. 3.3) czy obrzezaniem. Rania zwraca uwagę na to, że dostęp i prawo do kształcenia się jest podstawowym prawem każdego człowieka ${ }^{73}$.

W 1995 r. Rania, jeszcze jako księżniczka, założyła istniejącą do dziś Fundację Rzeki Jordan (The Jordan River Foundation). Instytucja ta miała poruszać tematy tabu, takie jak przemoc wobec dzieci i ich molestowanie, starać się im zapobiegać oraz, podobnie

\footnotetext{
Abdullah II, Our Last Best Chance..., s. 77-78.

Tamże, s. 80-81.

72 Tamże, s. 137.

73 Vision, oficjalna strona internetowa królowej Ranii, [online] http://www.queenrania.jo/rania/vision, 20 XII 2014.
} 
jak Fundacja Królowej Noor, wspierać przedsiębiorczość kobiet poprzez organizowanie różnego rodzaju projektów i szkoleń (np. z zakładania małych firm) ${ }^{74}$. Głównym celem fundacji jest realizacja dwóch szeroko zakrojonych programów. Pierwszy z nich dotyczy bezpieczeństwa dzieci (The Jordan River Child Safety Program ${ }^{75}$ ), drugi zaś - wspierania przedsiębiorczości i kreowania nowych perspektyw na przyszłość wśród społeczeństwa (The Jordan River Community Empowerment Program). Podobnie jak program Narodowego Rozwoju Rękodzieła, wspierany przez królową Noor, jest on skierowany głównie do kobiet i ma rozwijać ich wiedzę i umiejętności związane z produkcją tradycyjnych wyrobów rękodzielniczych. Zadaniem fundacji jest więc uświadamianie Jordańczykom, jaki jest ich gospodarczy potencjał, a także pokonywanie negatywnych zjawisk społecznych, będących niekiedy tematami tabu, tak jak molestowanie dzieci ${ }^{76}$.

W 2000 r. powstało centrum o nazwie Dar al-Aman, którego zadaniem jest niesienie pomocy ofiarom przemocy i molestowania. W placówce mieszka ok. 40 dzieci w różnym wieku. Wykwalifikowani pracownicy i wolontariusze są zobowiązani do stworzenia warunków bezpiecznego domu i zaszczepienia jego idei u podopiecznych. Dar al-Aman zapewnia dzieciom, które się w nim znalazły, dostęp do edukacji oraz pomoc psychologiczną i medyczną, np. konsultacje psychiatryczne czy zabiegi chirurgii plastycznej naprawiające to, co zostało uszkodzone wskutek przemocy ${ }^{77}$. Drugą placówką utworzoną przez fundację, przeznaczoną już nie tylko dla dzieci, ale dla całych rodzin, jest Centrum Królowej Ranii dla Rodzin i Dzieci (Queen Rania Family and Child Center), powstałe w 2005 r. we Wschodnim Ammanie, najuboższej dzielnicy miasta. Centrum ma zwalczać przemoc wobec dzieci i uświadamiać o sposobach jej zapobiegania. Placówka oferuje konsultacje psychologiczne dla rodziców i dzieci oraz maltretowanych kobiet czy pomoc w ramach grup wsparcia dla ofiar przemocy. Maltretowanym kobietom, oprócz wsparcia psychologa, zapewniana jest również podstawowa opieka medyczna oraz pomoc prawna ${ }^{78}$. Inną inicjatywą Fundacji Rzeki Jordan, również dotyczącą dzieci, jest program zapoczątkowany w 2007 r. o nazwie 110 dla Rodzin i Dzieci. „110" to numer bezpłatnej infolinii obsługiwanej przez psychologów ${ }^{79}$.

Drugim filarem działalności fundacji jest The Jordan River Community Empowerment, inicjatywa, której celem jest zmniejszanie ubóstwa poprzez docieranie do naj-

74 Abdullah II, Our Last Best Chance..., s. 83, 90.

75 About Us. Overview, oficjalna strona internetowa Fundacji Rzeki Jordan, [online] http://www.jordanriver.jo/?q=content/overview-2, 20 XII 2014.

76 Children. Overview, oficjalna strona internetowa Fundacji Rzeki Jordan, [online] http://www.jordanriver.jo/?q=content/jrcsp/overview, 20 XII 2014.

77 Dar Al Aman „DAA”, oficjalna strona internetowa Fundacji Rzeki Jordan, [online] http://www.jordanriver.jo/?q=content/jrcsp/dar-al-aman-daa, 20 XII 2014.

78 Queen Rania Family and Child Center, oficjalna strona internetowa Fundacji Rzeki Jordan, Centrum Królowej Ranii dla Rodzin i Dzieci, [online] http://www.jordanriver.jo/?q=content/jrcsp/queen-rania-family-and-child-center, 20 XII 2014.

79110 for Families and Children, oficjalna strona internetowa Fundacji Rzeki Jordan, 110 dla Rodzin i Dzieci, [online] http://www.jordanriver.jo/?q=content/jrcsp/110-families-and-children, 20 XII 2014. 
uboższych i podnoszenie ich kwalifikacji. Program jest przeznaczony głównie dla bezrobotnych, zamieszkujących najbiedniejsze regiony wiejskie. Społeczności nim objęte zrzeszane są w lokalne komitety, które mają motywować ludność do działania. Podobnie jak Fundacja Królowej Noor, Fundacja Rzeki Jordan wspiera rozwój tkactwa w wiosce Bani Hamida oraz zajmuje się szeroko pojętym wspieraniem rękodzielnictwa. Jednym z czołowych programów z tej dziedziny jest The Jordan River Designs Project, promujący tradycyjne hafty w kraju oraz poza jego granicami. Projekt ten zaangażował i dał możliwość zarobku ok. 1,5 tys. kobietom ${ }^{80}$.

Innym przedsięwzięciem, łączącym dbałość o środowisko naturalne, rozwój tradycyjnego rzemiosła oraz pomoc najbiedniejszym społecznościom, jest działający od 1997 r. Wadi Al Rayan Project. Obszar Wadi Al Rayan jest dość urodzajny, jego mieszkańcy (ok. 12 tys. osób) utrzymują się głównie z rolnictwa. Jednak, podobnie jak cała Jordania, teren ten cierpi z powodu ciągłych deficytów wody. Jest przy tym słabo rozwinięty gospodarczo, a jego głównymi problemami są: bieda, brak perspektyw zawodowych, szczególnie dla kobiet, niski poziom wykształcenia mieszkańców spowodowany ograniczonym dostępem do edukacji, brak umiejętności marketingowych lokalnej społeczności oraz wspomniany już chroniczny brak wody. Celem projektu jest stworzenie perspektywy zawodowo-zarobkowej dla miejscowych kobiet, które wykonują z liści banana oraz wyschniętej trzciny plecione kosze, podkładki pod szklanki, maty oraz inne akcesoria domowe. Kobiety mogą pracować w domu, projekt nie wymaga opuszczania rodzin ${ }^{81}$. Warto podkreślić, że jordańskie produkty rękodzielnicze są rzeczywiście dobrze wykonane i promowane, a ich cena nie należy do najniższych.

Działania fundacji są nakierowane również na młodzież; aktywizuje się ją głównie poprzez wolontariat, udział w projektach dających możliwość rozwoju kreatywności i przedsiębiorczości oraz ofertę szkoleniową. W 2007 r. Fundacja Rzeki Jordan w porozumieniu z International Business Leaders oraz korporacjami hotelarskimi rozpoczęła program Youth Career Initiative. Jego celem jest wzmocnienie pozycji młodych ludzi na rynku pracy i pomoc we właściwym wyborze zawodu ${ }^{82}$. Kolejną inicjatywą skierowaną do młodych ludzi jest Youth Work Jordan, projekt realizowany w latach 2010-2011 miał zwiększyć szanse na zatrudnienie poprzez rozwijanie umiejętności interpersonalnych, przedsiębiorczości oraz wspieranie małych infrastruktur o lokalnym zasięgu ${ }^{83}$.

Praca fundacji założonej przez królową Ranię jest doceniana na arenie międzynarodowej, o czym świadczą przyznane jej nagrody i wyróżnienia. W 2002 r. fundacja otrzymała międzynarodową nagrodę Society for Prevention of Child Abuse and

80 The Jordan River Designs Project, oficjalna strona internetowa Fundacji Rzeki Jordan, [online] http:// jordanriver.jo/?q=content/jrcep/jordan-river-designs-project, 20 XII 2014.

81 Wadi Al Rayan Project, oficjalna strona internetowa Fundacji Rzeki Jordan, [online] http://www.jordanriver.jo/?q=content/jrcep/wadi-al-rayan-project, 20 XII 2014.

82 Youth Career Initiative (YCI) (2007 and ongoing), oficjalna strona internetowa Fundacji Rzeki Jordan, [online] http://jordanriver.jo/?q=content/jrcep/youth-career-initiative-yci-2007-and-ongoing, data dostępu, 20 XII 2014.

83 Youth Work Jordan (YWJ) (2010-2011), oficjalna strona internetowa Fundacji Rzeki Jordan, [online] http://www.jordanriver.jo/?q=content/jrcep/youth-work-jordan-ywj-2010-2011, 20 XII 2014. 
Neglect za utworzenie pierwszego $\mathrm{w}$ świecie arabskim centrum pomocy ofiarom przemocy i molestowania - Dar al-Aman. W 2008 r. „Arabian Business Magazine” przyznało organizacji nagrodę za podejmowanie inicjatyw stymulujących rozwój przedsiębiorczości. W 2012 r. Fundacja Rzeki Jordan została wyróżniona przez Afro-Asian Rural Development Organization za wybitne zasługi we wspieraniu rozwoju obszarów wiejskich $^{84}$.

Działalność królowej Ranii poza fundacją skupia się na promocji Jordanii oraz podejmowanych przez nią inicjatyw w Internecie. Królowa regularnie aktualizuje swoje konta w serwisach internetowych YouTube, Twitter i Facebook, posiada również własną stronę internetową. Jej prowadzony od $2007 \mathrm{r}$. kanał w serwisie YouTube cieszy się dużą popularnością - posiada 38 tys. subskrypcji, a filmy wyświetlono $7 \mathrm{mln}$ razy ${ }^{85}$. Konto królowej w serwisie Twitter obserwuje około 3,5 mln osób, czyli prawie dziesięć razy tyle co królowej Noor. Rania pisze tam o swoim życiu prywatnym, wstawia zdjęcia $\mathrm{z}$ rodziną, porusza tematy gospodarcze, komentuje aktualne wydarzenia, promuje inicjatywy, którym patronuje ${ }^{86}$. Również na profilu w serwisie Facebook, który polubiło już 3,7 mln osób ${ }^{87}$, polecane są organizacje i przedsięwzięcia związane z działalnością królowej. Można na nim znaleźć zdjęcia przedstawiające królową realizującą projekty fundacji czy fotorelacje $\mathrm{z}$ ważnych wydarzeń międzynarodowych, w których brała udział. Nie brakuje również fotografii rodzinnych czy okolicznościowych - np. z okazji Dnia Matki królowa Rania dołączyła do życzeń zdjęcie ze swoją matką i córką ${ }^{88}$. Takie zabiegi mają ukazać królową jako dobrą matkę, żonę i córkę.

Królowa działa również na arenie międzynarodowej. Krótko po koronacji, we wrześniu 1999 r., wzięła udział w międzynarodowym Forum Pierwszych Dam, zorganizowanym przez Jolantę Kwaśniewską w Warszawie, poświęconym zagadnieniom takim, jak prawa dziecka oraz działalność charytatywna ${ }^{89}$. Jako osoba z wykształceniem ekonomicznym, Rania uczestniczy w konferencjach organizowanych przez Światowe

84 Memberships \& Awards, oficjalna strona internetowa Fundacji Rzeki Jordan, [online] http://jordanriver.jo/?q=content/memberships-awards, 20 XII 2014.

85 Oficjalny kanał królowej Ranii w serwisie internetowym YouTube, [online] http://www.youtube. com/user/QueenRania, 20 XII 2014. W 2008 r. serwis YouTube przyznał Ranii nagrodę YouTube Visionary Award za prowadzenie videobloga, na którym m.in. obalała stereotypy dotyczące islamu i Bliskiego Wschodu. S. Brummelhuis, You Tube Visionary Award for Queen Rania of Jordan, „The NextWomen Business Magazine", 11 XII 2008, [online] www.thenextwomen.com/2008/12/11/you-tube-visionary-award-for-queen-rania-of-jordan, 20 XII 2014; Queen Rania of Jordan Accepts the Visionary Award on YouTube Live '08., EzAd1992, 24 XI 2008, [online] https://www.youtube.com/ watch?v=IvZsQUFANiU, 20 XII 2014.

86 Oficjalne konto królowej Ranii w serwisie internetowym Twitter, [online] https://twitter.com/ QueenRania, 20 XII 2014.

87 Oficjalny profil królowej Ranii w serwisie internetowym Facebook, [online] https://www.facebook. com/QueenRania, 20 XII 2014.

Zdjęcie królowej z okazji Dnia Matki na oficjalnym profilu Ranii w serwisie internetowym Facebook, [online] https://www.facebook.com/photo.php?fbid=101505924513808268set=a $.88994910825 .98206 .77319320825 \&$ type=3\&theater, 20 XII 2014. 
Forum Ekonomiczne w szwajcarskim Davos, gdzie porusza tematy związane z problemami gospodarczo-społecznymi Jordanii czy całego Bliskiego Wschodu. Królowa jest również Ambasadorem UNICEF ${ }^{90}$.

Poza Fundacją Rzeki Jordan, królowa Rania zajmuje się również promowaniem edukacji. Najbardziej znanymi kampaniami prowadzonymi pod jej patronatem są inicjatywy Madrasati (Moja Szkoła) oraz 1GOAL Education for All. Pierwsza z nich, zapoczątkowana w 2008 r., obejmująca 500 szkół państwowych i współpracująca z ministerstwem edukacji, ma na celu odnowę jordańskiego systemu edukacji, uczynienie go bardziej interaktywnym, zachęcanie nauczycieli do odejścia od skostniałych schematów nauczania, m.in. poprzez szkolenie kadry nauczycielskiej, wsparcie finansowe szkół oraz zainteresowanie dzieci nauką ${ }^{91}$. W 2010 r. królowa rozpoczęła kampanię Madrasati w Palestynie - skierowano ją do 94 tys. dzieci w wieku szkolnym we Wschodniej Jerozolimie ${ }^{92}$. Postulatom nowoczesnego nauczania odpowiada Jordańskie Muzeum dla Dzieci w Ammanie, otwarte w 2007 r. z inicjatywy Ranii. Jest ono pierwszym interaktywnym muzeum w Jordanii, należącym do Międzynarodowego Stowarzyszenia Muzeów Dzieci z siedzibą w Waszyngtonie. Muzeum ma służyć inspirowaniu i pobudzaniu wyobraźni dzieci oraz ich naturalnej chęci zdobywania wiedzy, a także budowaniu świadomości ekologicznej. Jednakże, wciąż jest to jedna z niewielu tego typu placówek w Jordanii i dotarcie do dzieci, w szczególności z prowincji, nastręcza wiele trudności ${ }^{93}$.

$1 G O A L$ Education for All to $\mathrm{z}$ kolei kampania o zasięgu międzynarodowym. Program jest promowany głównie przez światowej sławy piłkarzy, polityków (np. Bill i Hillary Clinton) i celebrytów. Zainaugurowano go pod koniec 2009 r., podczas przygotowań do Mistrzostw Świata w Piłce Nożnej. Celem inicjatywy 1 GOAL jest zapewnienie dostępu do edukacji dla $75 \mathrm{mln}$ dzieci do 2015 r. Od 2011 r. program koncentruje się na kwestii dostępu dziewcząt do edukacji ${ }^{94}$.

Królowa Rania prowadzi szeroko zakrojoną działalność społeczną, którą nagłaśniają media, zarówno lokalne, jak i zagraniczne. Wykorzystuje w tym celu sieć placówek działających pod jej patronatem. Sama wydaje się ucieleśnieniem propagowanych wartości, ma bowiem wyższe wykształcenie, jest przedsiębiorcza, a przy tym opiekuje się domem i jest żoną oraz matką. W ten sposób przyczynia się do kreowania wizerunku

90 Relacja z konferencji w Davos w 2010 r.: WEF: Think «Business Unusual», oficjalna strona internetowa królowej Ranii, 31 I 2010, [online] http://www.queenrania.jo/blog/wef-think-business-unusual, 20 XII 2014.

91 Oficjalna strona internetowa inicjatywy Madrasati, [online] http://www.madrasati.jo/site.html, 20 XII 2014.

92 Abdullah II, Our Last Best Chance..., s. 140.

93 Oficjalna strona internetowa The Children's Museum Jordan, [online] http://www.cmj.jo, 20 XII 2014; King, Queen Join Jordanian Children at Opening of Children's Museum, oficjalna strona internetowa królowej Ranii, 24 V 2007, [online] http://www.queenrania.jo/media/articles/king-queen-join-jordanian-children-opening-childrens-museum, 20 XII 2014.

94 About 1GOAL, oficjalna strona internetowa kampanii 1GOAL Education for All, [online] http:// www.join1goal.org/about-1GOAL.php, 20 XII 2014. 
Jordanii jako państwa nowoczesnego, tolerancyjnego, troszczącego się o swoich obywateli, a jednocześnie szanującego tradycje i religię.

\subsection{Pozycja kobiety i kontrowersje wokół wizerunku Jordanii}

Obecna królowa Jordanii i jej mąż są znani także z wystąpień potępiających tzw. zabójstwa (lub zbrodnie) honorowe ${ }^{95}$. Jak pokazują badania prowadzone przez Beatę Kowalską, znaczna większość zarówno ich ofiar, jak i sprawców nie posiada wyższego wykształcenia, a ok. jedną czwartą stanowią analfabeci ${ }^{96}$. Na to, jak bardzo zakorzenione jest pojęcie honoru w całym społeczeństwie arabskim, szczególnie jordańskim, zwraca uwagę Ewa Górecka. Twierdzi ona, że kwestia reputacji kobiety stanowiła bardzo ważny aspekt już w okresie przedislamskim, a tendencja do postrzegania honoru mężów oraz całych rodzin przez pryzmat kobiet utrzymuje się do dzisiaj ${ }^{7}$. Według danych ONZ w Jordanii co roku ginie ok. 20 kobiet, co stanowi ok. 20\% wszystkich udokumentowanych zabójstw w Haszymidzkim Królestwie. Często zdarza się, że przyczyną morderstwa nie jest przyłapanie kobiety na cudzołóstwie, a np. gwałt, ogromna presja społeczna, plotki dotyczące nieskromnego ubioru czy zachowania dziewczyny ${ }^{98}$. Jak twierdzi król Abd Allah II, dzięki kampaniom społecznym popieranym przez pałac królewski czy organizowanym przez komitety kobiece liczba zabójstw honorowych spada. W 2008 r. odnotowano 13 takich przypadków, a w 2009 r. - 10. Sprawcy, którzy popełnili zbrodnie w 2009 r., zostali skazani na 10 lat więzienia; wcześniej kary wynosiły od pół roku do dwóch lat pozbawienia wolności ${ }^{99}$. Jordański kodeks karny nie chroni jednak ofiar morderstw honorowych. Chodzi głównie o kontrowersyjne art. 98 i 340, które do niedawna wykorzystywano do całkowitego zwolnienia z odpowiedzialności karnej bądź wymierzenia wspomnianej niskiej kary ${ }^{100}$. Co więcej, potencjalne ofiary nie moga szukać bezpiecznej kryjówki w schronisku dla ofiar przemocy, ponieważ regulamin tej instytucji tego zabrania ${ }^{101}$.

Niedługo po objęciu tronu przez Abd Allaha II CNN zrealizowało krótki film dokumentalny dotyczący zabójstw honorowych w Jordanii, co odbiło się niekorzystnie na wizerunku Haszymidzkiego Królestwa, szczególnie za granicą. Król zareagował, naciskając na rząd, by doprowadził do wprowadzenia w kodeksie karnym poprawek, które znio-

\footnotetext{
Abdullah II, Our Last Best Chance..., s. 138.

B. Kowalska, Kobiety, rozwój, obywatelstwo w Haszymidzkim Królestwie Jordanii, Kraków 2013, s. 263.

97 E. Górecka, Znaczenie honoru kobiety w opinii wspótczesnego spoteczeństwa jordańskiego, Łódź 2009. B. Kowalska, Kobiety, rozwój, obywatelstwo..., s. 247, 260-261.

Abdullah II, Our Last Best Chance..., s. 138.

Art. 340 kodeksu mówi, że: a) Ten kto nakryje swoją żonę lub krewną na cudzotóstwie z obcym mężczyzna i zabije lub rani któreś z nich, jest zwolniony z odpowiedzialności karnej. b) Ten kto nakryje swojążone lub krewna z obcym mężczyzna na niezgodnym z prawem stosunku i zabije lub rani któreś z nich, korzysta $z$ redukcji kary. Natomiast według art. 98: Ten, kto popetnia zbrodnie w stanie najwyższego wzburzenia spowodowanego niedozwolonym czy w jakimśstopniu niebezpiecznym zachowaniem ofiary, korzysta z redukcji kary. B. Kowalska, Kobiety, rozwój, obywatelstwo..., s. 258 
słyby niesprawiedliwe wobec kobiet przepisy. Grupa Jordańczyków, pod przewodnictwem dziennikarki śledczej „The Jordan Times” Rany Husseini ${ }^{102}$, utworzyła Narodowy Jordański Komitet do spraw Wyeliminowania tak zwanych Morderstw Honorowych. Rozpoczął on akcję zbierania podpisów pod projektem zmiany art. 340, odnoszącego się bezpośrednio do cudzołóstwa. Tuż przed ogłoszeniem działalności komitetu w mediach jordański minister sprawiedliwości poinformował, że w parlamencie został przekazany pod głosowanie wniosek o zniesienie art. 340. W uzasadnieniu podawano, iż narusza on konstytucję, zezwalając na samosąd, ponadto gwarantując łagodniejsze wyroki mężczyznom, dyskryminuje kobiety. Nie był on też zgodny z islamem, który wymaga potwierdzenia cudzołóstwa przez czterech świadków, a międzynarodowe organizacje humanitarne nieustannie go krytykowały. Ostatni punkt spotkał się z ostrym potępieniem konserwatywnych środowisk, które stwierdziły, że kampania jest inspirowana przez Zachód, a jej zadaniem jest zniszczenie podstaw moralności społecznej i nawoływanie do rozwiązłości. Uczeni związani z Frontem Akcji Islamskiej wydali fatwę nawołującą do zachowania art. 340 jako [...] ostatniej fortecy chroniacej spoteczna moralnośćc ${ }^{103}$. Mimo poparcia, czy wręcz przejęcia inicjatywy przez rodzinę królewską, projekt zmiany artykułu został odrzucony przez niższą izbę parlamentu. Wizerunek pałacu królewskiego wzmocnił się jednak na arenie zarówno międzynarodowej, jak i lokalnej ${ }^{104}$.

Kolejną kontrowersyjną kwestią pozostaje sprawa przekazywania obywatelstwa: Jordanki, które wyszły za mąż za obcokrajowców, nie mogą przekazać obywatelstwa swoim dzieciom i mężom. Choć stopień emancypacji kobiet w Jordanii jest relatywnie wysoki (kobiety są obecne w parlamencie, w 1996 r. pierwsza kobieta została sędzią), w kwestii obywatelstwa są one dyskryminowane. W listopadzie 2002 r. podczas II Szczytu Kobiet Arabskich w Ammanie królowa zapewniła Jordanki, że mają zostać wprowadzone zmiany w prawie, które zagwarantowałyby im konstytucyjną równość, w tym równe prawo do obywatelstwa. Sytuacja jednak do dziś nie uległa zmianie ${ }^{105}$.

Rania jest postrzegana - szczególnie na Zachodzie - jako krzewicielka edukacji i tolerancji oraz przedstawicielka nowoczesnej elity arabskiej. Często nazywa się ją Księżna Diana Bliskiego Wschodu ${ }^{106}$. W wywiadzie przeprowadzonym przez słynną amerykańską prezenterkę telewizyjną Oprah Winfrey królowa została przedstawiona

102 Rana Husseini jako pierwsza przełamała społeczne tabu i poruszyła publicznie temat tzw. zbrodni honorowych, publikując w 1994 r. artykuł Murder in the name of honor. Opowiedziała w nim historię zgwałconej przez brata szesnastolatki, zmuszonej przez rodzinę do przeprowadzenia zabiegu aborcji, a następnie wydanej za mąż za wiele starszego mężczyznę. Po pół roku małżeństwa dziewczyna chciała się rozwieść, ale wtedy jej matka, bracia i wuj zdecydowali, iż musi zostać zabita. Oprawcą był jeden z braci. Tamże, s. 266 .

103 Tamże, s. 273.

104 Tamże, s. 267-272.

105 Tamże, s. 5, 151-152.

106 Strony internetowe, na których Rania porównywana jest do księżnej Diany: J. Clibbon, Queen Rania Al-Abdullah: A Diplomatic Monarch in a Troubled Region, CBC News, 3 X 2010, [online] http:// www.cbc.ca/news/world/story/2010/09/30/f-queen-rania-al-abdullah-bio-and-interview.html, 24 I 2015; Gale Encyclopedia of Biography: Rania Al-Abdullah, [online] http://www.answers.com/ topic/queen-rania-of-jordan, 24 I 2015. 
jako wzorowa matka oraz międzynarodowa ikona mody, która stara się uczynić świat lepszym, szczególnie dla kobiet i dzieci ${ }^{107}$. Rania bardzo często jest wyróżniana przez międzynarodowe czasopisma kobiece i modowe jako jedna z najlepiej ubranych pierwszych dam czy słynnych kobiet w ogóle. Przykładem może być ranking miesięcznika „Vanity Fair” ${ }^{108}$, w którym królowa wyprzedziła m.in. Michelle Obamę czy wspominaną wcześniej Mozę bint Nasser. Wydaje się jednak, że nowoczesny styl królowej nie oddziałuje na większość Jordanek, które wolą zasłaniać włosy chustą i nosić długie płaszcze. Stroje królowej Ranii, mimo wielu pochwał, są również ciągłym obiektem krytyki, szczególnie konserwatywnych środowisk islamskich. Ranii wytyka się to, iż ubiera się w zachodni sposób, nie zasłania włosów, czasami odkrywa ramiona, a jej modne kreacje, pochodzące od znanych projektantów, są bardzo kosztowne ${ }^{109}$. Zarzuca się jej też to, że robi wokół siebie zbyt dużo szumu medialnego, a promowane przez nią akcje nie sprawdzają się w jordańskiej rzeczywistości.

Badania socjologiczne przeprowadzone w 2011 r. na grupie 1006 mężczyzn i 1005 kobiet $\mathrm{z}$ różnych części Jordanii pokazują, że tylko $2 \%$ rodziców uznaje media i prawo za znaczące źródła ich postaw rodzicielskich determinujących sposób wychowania córek. W znacznej większości rodzin chłopcy stoją na uprzywilejowanej pozycji, a dziewczęta są odsuwane na dalszy plan. Aż $90 \%$ badanych uważa, iż córki powinny być posłuszne swoim braciom. Badania miały także pokazać, jak takie podejście wpływa na postrzeganie przez dziewczęta swojej roli w społeczeństwie. W tym celu przebadano 120 dziewcząt z 5 jordańskich miast. Badania wykazały, że dziewczęta nie uważają swojej roli społecznej za ważną, a szkoła nie jest miejscem osobistego rozwoju i brak w niej kreatywnych metod nauczania ${ }^{110}$. Beata Kowalska tak opisuje m.in. rezultaty tych badań: [...] jedynymi osobami publicznymi, które skupiaja na sobie wiele uwagi dziewczat, jest para królewska. Atrakcyjność fizyczna, ideat partnera czy pomoc potrzebujacym to najczęstsze powody, dla których król i królowa darzeni są szczególna atencja. [...] niemal każdy program informacyjny zaczyna się od informacji o wizycie króla lub królowej w sierocińcu, szkole czy szpitalu. Ujawnia się tutaj jeszcze jeden interesujacy aspekt - w sytuacji dotkliwej niesprawiedliwości, nieszczęścia, choroby, wyobrażona pomoc zawsze przychodzi ze strony stawnej lub bogatej osoby. System instytucji, które w takiej sytuacji sa powotane do niesienia pomocy, podjęcie walki o zmiane swojego potożenia, w wyobrażeniach badanych dziewczat nie istnieja ${ }^{111}$.

Kolejną kwestią, za którą królowa bywa krytykowana, jest jej palestyńskie pochodzenie. Jak twierdzi Avi Shlaim, autor obszernej biografii królaHusajna I, fakt, że Rania

107 Queen Rania's Full Oprah Interview, VideoHatCom, 15 IX 2012, [online] https://www.youtube. com/watch?v=9ehpVlauStM, 20 XII 2014.

108 Ranking najlepiej ubranych pierwszych dam: First and Finest, „Vanity Fair”, 15 III 2013, [online] www.vanityfair.com/style/2013/03/photos-best-dressed-first-ladies, 20 XII 2014.

109 Jordanian Royal Family and the Conspiracy of Islamic Caliphate, oficjalna strona internetowa organizacji Correct Islamic Faith International Association, [online] http://www.cifiaonline.com/factaboutjordanroyals.htm, 20 XII 2014.

110 B. Kowalska, Kobiety, rozwój, obywatelstwo..., s. 286-291.

111 Tamże, s. 291-292. 
ma palestyńskie korzenie, mógł przyczynić się do wyznaczenia na następcę tronu Abd Allaha. Nowa królowa miała pomóc w rozwiązywaniu konfliktów wśród palestyńskiej części mieszkańców Jordanii ${ }^{112}$. Mimo tego palestyńskie pochodzenie królowej nie jest pozytywnie postrzegane wśród rdzennych Jordańczyków, w tym przywódców plemiennych. Świadczy o tym wspominany już wcześniej list otwarty wystosowany do króla Abd Allaha II, w którym skrytykowano zbyt znaczący wpływ królowej na politykę. Zarzucono jej nepotyzm oraz działanie na niekorzyść Jordańczyków z jednoczesnym wspieraniem Palestyńczyków. Bardzo poważnym zarzutem było też okradanie skarbu państwa i przekazywanie pieniędzy oraz ziemi swojej rodzinie ${ }^{113}$.

Jordańczycy zarzucają jednak królowej głównie to, że skupia na sobie zbyt dużą uwagę mediów, a jej sposób bycia jest zbyt drogi. Powiela się niekiedy plotki na temat finansowego wspierania rodziny. Natomiast o królowej Noor rzadko można usłyszeć niepochlebne opinie, często za to podkreśla się jej skromność i nieafiszowanie swoją działalnością. Odmienne opinie mogą wynikać z różnych osobowości pierwszych dam, różnicy wieku między nimi oraz różnego pochodzenia.

Pomimo głosów krytyki wewnątrz państwa, królowa Rania jest bardzo pozytywnie postrzegana poza granicami Haszymidzkiego Królestwa. To właśnie dzięki aktywności królowej Jordania jawi się na Zachodzie jako państwo otwarte i wspierające rozwój edukacji. Nie znaczy to jednak, że działalność Ranii jest niedoceniona przez rodaków, a gloryfikowana tylko w Europie czy w Stanach Zjednoczonych. W 2012 r. królowa znalazła się na 37. miejscu w rankingu The Muslim 500, obejmującym 500 najbardziej wpływowych muzułmanów na świecie ${ }^{114}$. W kolejnych dwóch edycjach uplasowała się na 32. pozycji. Wydaje się, że zarzuty, jakoby działalność charytatywna Ranii była tylko fasadowa, są krzywdzące, ponieważ kampanie na rzecz rozwoju edukacji czy inicjatywy prowadzone przez Fundację Rzeki Jordan realnie wspierają Jordańczyków i wpływają pozytywnie na rozwój Haszymidzkiego Królestwa.

\section{PODSUMOWANIE}

Polityka wizerunkowa wymaga wielu złożonych i długofalowych działań, by przekonać zarówno obywateli, jak i opinię międzynarodową do swoich działań. Haszymidzi od powstania królestwa w 1946 r. robili wszystko, by zjednać sobie różne warstwy społeczne i stworzyć stabilny system polityczny. O skuteczności ich polityki przekonały wydarzenia tzw. Arabskiej Wiosny, które nie doprowadziły do zmiany władzy w Jordanii.

112 A. Shlaim, Lion of Jordan..., s. 593.

113 Artykuły BBC News i izraelskiego Ynetnews dotyczące listu wystosowanego przez przywódców plemion beduińskich: Jordan Tribes Criticise Queen Rania's «Political Role», BBC News, 8 II 2011, [online] http://www.bbc.co.uk/news/world-middle-east-12400274, 24 I 2015; R. Simioni, «Queen Rania Is a Corrupt Thief», Ynetnews, 14 II 2011, [online] www.ynetnews.com/articles/0,7340,L-4028607,00.html, 24 I 2015.

114 Ranking The Muslim 500, The 500 Most Influential Muslims, 2012, [online] http://themuslim500. com/profile/h-m-queen-rania-al-abdullah, 20 XII 2014. 
Król Abd Allah II i królowa Rania kreują wizerunek Jordanii jako państwa tolerancyjnego, otwartego na Zachód, jednak niewypierającego się tradycji i dziedzictwa religijnego. Obraz rodziny królewskiej jest przedstawiany w sposób atrakcyjny dla współobywateli ${ }^{115}$. Wizerunek demokratyzującego się, walczącego o prawa człowieka państwa nie współgra jednak z ciągle obecną cenzurą, nierównym dostępem do obywatelstwa oraz dyskryminującymi kobiety przepisami prawa.

Królowa Rania stworzyła wizerunek siebie jako arabskiej kobiety sukcesu i tak bez wątpienia jest postrzegana wśród zagranicznych obserwatorów. W przeciwieństwie do swojej poprzedniczki, królowej Noor, Rania pracuje nie tylko na wizerunek swojego męża. Dzięki zręcznemu wykorzystaniu najnowszych technologii, stworzyła ona obraz rzeczniczki praw kobiet i dzieci, wypowiadającej się na Forum Ekonomicznym w Davos i docenianej w opinii międzynarodowej. Podobnie jak Hillary Clinton, królowa nie jest znana jedynie jako żona swojego męża. W zagranicznych magazynach często przedstawia się ją jako ikonę stylu i elegancji. Wiedząc, jaką siłę mają media, królowa sama je kreuje, regularnie korzystając z mediów społecznościowych, co nie zawsze jest przychylnie odbierane wewnątrz państwa, szczególnie wśród społeczności beduińskiej bądź fundamentalnych ugrupowań islamskich. Ranii często wypomina się palestyńskie korzenie czy zbyt duży szum medialny, jaki wywołuje wokół siebie, a także zamiłowanie do drogich, zachodnich strojów. Mimo tych zarzutów, królowa konsekwentnie pozostaje aktywnym i istotnym uczestnikiem jordańskiego życia publicznego.

\section{BIBLIOGRAFIA}

\section{Publikacje drukowane:}

\section{Literatura źródłowa:}

Abdullah II, Our Last Best Chance. A Story of War and Peace, New York 2012.

Noor, Autobiografia. Opowieść o nieoczekiwanym życiu, przeł. B. Cendrowska, Warszawa 2003.

\section{Literatura pomocnicza:}

- monografie i opracowania:

Górecka E., Znaczenie honoru kobiety w opinii wspótczesnego spoteczeństwa jordańskiego, Łódź 2009.

Kowalska B., Kobiety, rozwój, obywatelstwo w Haszymidzkim Królestwie Jordanii, Kraków 2013.

Madeyska D., Historia wspótczesna świata arabskiego, Warszawa 2008.

Shlaim A., Lion of Jordan. The Life of King Hussein in War and Peace, New York 2008.

Wróblewski B., Jordania, Warszawa 2011.

Zdanowski J., Bliski Wschód 2011. Bunt czy rewolucja?, Kraków 2011.

Zdanowski J., Historia Bliskiego Wschodu w XX wieku, Wrocław 2010.

115 I. Król, Sposoby kreowania wizerunku monarchy..., s. 167. 
- rozdziały w pracach zbiorowych:

Giereło K., Wizerunek (image) polityka - teoria i praktyka, [w:] Public relations w teorii i praktyce, red. B. Ociepka, Wrocław 2002.

Król I., Sposoby kreowania wizerunku monarchy w Jordanii, Maroku i Arabii Saudyjskiej, [w:] Kultura popularna na Bliskim Wschodzie, red. nauk. K. Górak-Sosnowska, K. Pachniak, Warszawa 2013.

- artykuły w czasopismach naukowych:

Chen Y. Y., Fang W. C., The Moderating Effect of Impression Management on the Organizational Politics - Performance Relationship, „Journal of Business Ethics” 2008, vol. 79, nr 3, [online] http://dx.doi.org/10.1007/s10551-007-9379-3.

Czornik K., Królestwo Jordanii w polityce Stanów Zjednoczonych wobec Bliskiego Wschodu w okresie pozimnowojennym, „Studia Politicae Universitatis Silesiensis” 2014, t. 12.

Felson R. B., Aggression as Impression Management, „Social Psychology” 1978, vol. 41, nr 3, [online] http://dx.doi.org/10.2307/3033557.

Leak G. K., Fish S., Religious Orientation, Impression Management, and Self-Deception: Toward a Clarification of the Link between Religiosity and Social Desirability, ,Journal for the Scientific Study of Religion” 1989, vol. 28, nr 3, [online] http://dx.doi.org/10.2307/1386746.

Malantowicz A., Buforowość jako wyznacznik polityki zagranicznej Jordanii, „Stosunki Międzynarodowe” 2014, vol. 49, nr 1.

Rosenfeld P., Impression Management, Fairness, and the Employment Interview, "Journal of Business Ethics" 1997, vol. 16, nr 8, [online] http://dx.doi.org/10.1023/A:1017972627516.

- artykuły prasowe:

Moon Y., Democracy on the Horizon: How the Arab Spring is Unfolding in Jordan, "Harvard International Review" 2012, vol. 33, issue 4, s. 28.

Wrzesień A., Wszystkie dzieci sq nasze, „Przekrój”, 10 X 1999.

\section{Publikacje elektroniczne:}

\section{Literatura źródłowa:}

The Constitution of The Hashemite Kingdom of Jordan January 1, 1952, [online] http://www. kinghussein.gov.jo/constitution_jo.html. Queen Rania of Jordan Accepts the Visionary Award on YouTube Live '08., EzAd1992, 24 XI 2008, [online] https://www.youtube.com/ watch?v=IvZsQUFANiU.

Queen Rania's full Oprah Interview, VideoHatCom, 15 IX 2012, [online] https://www.youtube.com/watch?v=9ehpVlauStM.

\section{Literatura pomocnicza:}

- monografie i opracowania:

Democracy index 2010. Democracy in retreat. A report from the Economist Intelligence Unit, London 2010, [online] https://graphics.eiu.com/PDF/Democracy_Index_2010_web.pdf. Democracy index 2011. Democracy under stress. A report from the Economist Intelligence Unit, London 2011, [online] http://www.eiu.com/public/topical_report.aspx?campaignid= DemocracyIndex2011. 
Democracy index 2012. Democracy at a standstill. A report from The Economist Intelligence Unit, London 2013, [online] http://www.eiu.com/public/topical_report.aspx?campaignid= DemocracyIndex 12 .

Democracy index 2013. Democracy in limbo. A report from The Economist Intelligence Unit, London 2014, [online] http://www.eiu.com/public/topical_report.aspx?campaignid= Democracy0814.

DemocracyIndex 2014. Democracyanditsdiscontents. Areportfrom The Economist Intelligence Unit, London 2015, [online] http://www.eiu.com/public/topical_report.aspx ?campaignid= Democracy0115.

The Economist Intelligence Unit's index of democracy. The World in 2007, London 2007, [online] http://www.economist.com/media/pdf/DEMOCRACY_INDEX_2007_v3.pdf.

The Economist Intelligence Unit's Index of Democracy 2008, London 2009, [online] http://graphics.eiu.com/PDF/Democracy\%20Index\%202008.pdf.

- artykuły prasowe:

Brummelhuis S., You Tube Visionary Award for Queen Rania of Jordan, „The NextWomen Business Magazine", 11 XII 2008, [online] www.thenextwomen.com/2008/12/11/ you-tube-visionary-award-for-queen-rania-of-jordan.

Clibbon J., Queen Rania Al-Abdullah: A Diplomatic Monarch in a Troubled Region, CBC News, 3 X 2010, [online] http://www.cbc.ca/news/world/story/2010/09/30/f-queen-rania-al-abdullah-bio-and-interview.html.

First and Finest, „Vanity Fair”, 15 III 2013, [online] www.vanityfair.com/style/2013/03/ photos-best-dressed-first-ladies.

Jordan Carries Out New Air Strikes After Pilot's Murder, www.theguardian.com, 5 II 2015, [online] http://www.theguardian.com/world/2015/feb/05/jordan-air-strikes-isis-pilotmurder.

Jordan Tribes Criticise Queen Rania's «Political Role», BBC News, 8 II 2011, [online] http:// www.bbc.co.uk/news/world-middle-east-12400274.

Mezzofiore G., No, Jordan's King Abdullah II Is Not Personally Flying Planes Against Isis, „International Business Times”, 5 II 2015, [online] http://www.ibtimes.co.uk/ no-jordans-king-abdullah-ii-not-personally-flying-planes-against-isis-1486742.

Nordland R., Kirkpatrick D. D., Jordan's King Abdullah II Returns Home to Cheers After Swift Executions, www.nytimes.com, 4 II 2015, [online] http://www.nytimes.com/2015/02/05/ world/middleeast/jordans-king-abdullah-ii-returns-home-to-cheers-after-swift-executions. html?_r=0.

Simioni R., «Queen Rania Is a Corrupt Thief», ynetnews.com, 14 II 2011, [online] www.ynetnews.com/articles/0,7340,L-4028607,00.html.

Zagner A., Żony dyktatorów, „Polityka”, 29 V 2012, [online] www.polityka.pl/tygodnikpolity$\mathrm{ka} /$ swiat/1527171,1,kochane-nienawidzone-nieznane-arabskie-pierwsze-damy.read.

- inne:

Arab Reform Initiative, Arab democracy index, [online] http://www.arab-reform.net/sites/default/files/ADI-IV_Mastersheet.pdf.

Biographical Information. Her Majesty Queen Noor of Jordan, strona internetowa poświęcona królowi Husajnowi, [online] http://www.kinghussein.gov.jo/queen_noor.html. 
Gale Encyclopedia of Biography: Rania Al-Abdullah, [online] http://www.answers.com/topic/ queen-rania-of-jordan.

June Ferguson's Royal Genealogy Page, RootsWeb.com, [online] http://wc.rootsweb.ancestry. com/cgi-bin/igm.cgi?op=GET\&db=royals\&id $=I 33912$.

Ranking The Muslim 500, The 500 Most Influential Muslims, [online] http://themuslim500. com/profile/h-m-queen-rania-al-abdullah.

\section{Strony internetowe:}

Oficjalna strona internetowa The Children's Museum Jordan, [online] http://www.cmj.jo.

Oficjalna strona internetowa Fundacji Rzeki Jordan, [online] http://www.jordanriver.jo.

Oficjalna strona internetowa inicjatywy Madrasati, [online] http://www.madrasati.jo.

Oficjalna strona internetowa króla Abd Allaha II, [online] http://kingabdullah.jo.

Oficjalna strona internetowa królowej Ranii, [online] http://www.queenrania.jo/rania/vision.

Oficjalna strona internetowa Mozy bint Nasser, [online] http://www.mozabintnasser.qa.

Oficjalne konto królowej Ranii w serwisie internetowym Twitter, [online] https://twitter.com/ QueenRania.

Oficjalny kanał królowej Ranii w serwisie internetowym YouTube, [online] http://www.youtube.com/user/QueenRania.

Oficjalny profil królowej Ranii w serwisie internetowym Facebook, [online] https://www.facebook.com/QueenRania.

Strona internetowa kampanii 1GOAL Education for All, [online] http://www.joinlgoal.org/ about-1GOAL.php.

Strona internetowa organizacji Correct Islamic Faith International Association, [online] http:// www.cifiaonline.com.

Strona internetowa The Honor Society of Nursing, Sigma Theta Tau International, [online] http://www.nursingsociety.org.

Strona internetowa The World Factbook, Central Intelligence Agency, [online] https://www. cia.gov/library/publications/the-world-factbook.

Katarzyna ANDRYS, studentka II roku studiów II stopnia na kierunku studia azjatyckie o specjalności bliskowschodniej na Uniwersytecie Jagiellońskim. Uczestniczka kursów prowadzonych na Uniwersytecie Jordańskim i Kairskim. Autorka rozdziału Sytuacja spoteczno-polityczna kobiet w Egipcie podczas rządów Husniego Mubaraka i po jego obaleniu w książce Porewolucyjny Egipt. Wybrane aspekty spoteczne i polityczne pod redakcją Piotra Nizińskiego i Michała Lipy (Kraków 2014). Przedmiot zainteresowań naukowych autorki stanowią szeroko pojęte kwestie społeczne i polityczne w regionie Bliskiego Wschodu ze szczególnym uwzględnieniem Jordanii i Egiptu, a także język arabski. 